\title{
'THE STORY YOU WERE TELLING US': RE-READING LOVE IN ALICE WALKER'S BY THE LIGHT OF MY FATHER'S SMILE THROUGH LUCE IRIGARAY'S THEORY
}

\section{Özlem Gorey \\ Bogaziçi University}

This article considers Alice Walker's novel By the Light of My Father's Smile in the light of the theories of French feminist Luce Irigaray. It concentrates particularly on the redefinition of love through the creation of a maternal genealogy. It explores how the severe punishment of one of the daughters, as a result of her love affair with a young Indian boy, results in the deep scarring of all the family for the rest of their lives. Interpreting this traumatic event as a metaphorical Oedipal break from the mother, this discussion aims to show the ways in which both the novelist and the theoretician explore the possibility of redefining the term 'love' through the mother-daughter relationship.

Alice Walker needs no introduction as she has been a forerunner in the arena of the feminist movement and feminist studies or "womanism," a phrase coined by the author herself, not only with her fiction, poetry, and prose, but also with her prominent role in civil rights activism. The Color Purple (1982) placed her in the literary canon as a writer who centralizes the experiences of black women against both racism and violence inherent in societal patriarchy. She went on to explore these issues in Possessing the Secret of Joy which dealt with the physical and 


\section{Ethnic Studies Review Volume 26: 1}

psychological brutality of female circumcision. Her novel, By the Light of My Father's Smile (1998), further delineates the harmful ways in which the culture we live in suppresses female sexuality and presents alternatives through which the overused concept of love could be redefined in relation to the female experience.

Walker's definition of the term, "womanism," in In Search of Our Mother's Gardens, informs the analysis in this article. A womanist, Walker argues, is a "black feminist or feminist of color." She is a "woman who loves other women sexually and/or non-sexually [and who] appreciates and prefers women's culture, women's emotional flexibility. . . women's strength." She further explains the phrase as "usually referring to outrageous, audacious, courageous or willful behavior. Wanting to know more and in greater depth than is considered "good" for one." More importantly within the context of this article, a womanist is "committed to survival and wholeness of entire people, male and female" (Ixi-xii).

By the Light of My Father's Smile could be read as a tentative step towards the above-mentioned goals identified by the author. One of the constant themes throughout the industrious career of Alice Walker seems to be the urgent need for the redefinition of love through the creation of a maternal genealogy. It could be argued that the feminist imperative to propose new ways of conceptualizing women's relationship with each other individually and as a community serves as a significant guideline for Walker in this novel. The mother-daughter relationship in its metaphorical sense could be placed at the core of all these issues. By the Light of My Father's Smile demonstrates how the abandonment of this intimate relationship results in the impossibility of self-love on behalf of the woman and also becomes the foundation for the myth of the selfless woman.

I interpret this novel using the theories of the French feminist, Luce Irigaray, who also underlines the necessity of recovering the broken, or rather the abandoned and forgotten, bond of love between mother and daughter as well as between women as sisters, as hard as this is to establish within a patriarchal system of thought. In order to be regarded as a 'normal' woman, Freud tells us, the girl's Oedipus complex must lead to the abandonment of her attachment to her primary love object, her moth- 
er, in favour of the father and divert her love and desire towards the man-father; however she must at the same time also retain some identification with the mother in order to acquire the necessary feminine attributes. Hence she must preserve a degree of identification with the "castrated" mother, a position that cannot enable her to possess an autonomous identity. What needs to be contested is not the description of this model but the necessity and the inevitability of it. According to the Freudian model the forceful abdication of the mother as the primary love object serves as a vital gesture that sustains the male-oriented understanding of the concept of love that involves domination and possession. Ultimately, as Irigaray explains in An Ethics of Sexual Difference, love between women cannot occupy a space of its own within this concept. According to French feminism lack of positive feminine representation stems from the severed motherdaughter bond. As a theoretician Irigaray does not break away completely from the Freudian model but instead advocates a return to the pre-Oedipal phase of development, a time before patriarchal divisions have taken place, to recover the bond between the mother and the child. Such a recovery would allow her to move away from the compulsory identification with the submissive mother who is powerless and passive under the law of the father; hence both the mother and the daughter could be provided with an adequate space for a specific female subjectivity through which love between women can exist.

Alice Walker also embraces the need for a genealogy of women, a history of maternal connections and relations, which would lead to a definition of love by and for the female self. She seems to locate a possible place from which to maneuver and initiate change in her exploration of the mother-daughter relationship and female relations. What both Irigaray and Walker are struggling to envision, however, is not a project limited to the maternal function but rather a genealogy of women which is based on the recovery of maternal connections and a bond of love that have been effaced throughout a dominantly white patriarchal history.

With these ideas in mind I turn to By the Light of My Father's Smile. The father mentioned in the title is Robinson, an anthropologist who has to masquerade as a Christian missionary in 


\section{Ethnic Studies Review Volume 26: 1}

order to fund his research on the Mundo people, a mixed race of escaped Black slaves and native Indians in Mexico. During the time the family spends in Mexico an event takes place which effectively ruins the lives of Robinson and his family, his wife Langley, and their two daughters, Magdalena and Susannah. The elder daughter, Magdalena, has a love affair with a beautiful Indian boy called Manuelito. When the father discovers the affair he beats Magdalena with a belt severely punishing his daughter for an act of love. Psychologically estranged from both of his daughters for the rest of his life as a result of his actions, Robinson only has access to his daughters' real feelings as an angel after his death.

The father's act of punishment of the daughter for her own good, which is referred to as the 'breaking of her' in the novel, also results in the alienation of the sisters from each other and from their mother. The severe beating of Magdalena serves as the entry into the symbolic order which necessitates the abandonment of her mother. It is through the power and violence of the father that the girls, Magdalena in particular, are introduced to the so-called realities of life. This act of violence, a sort of painful and prescribed Oedipal break, is the embodiment of the girls' entry into patriarchal order. The lack of power and the submissiveness of the mother fits within the Freudian model and further secures the break. The transition from the loving and secure nature of the Mundo tribe with its deep respect for both physical and spiritual love into the patriarchal Christian world of the father could be read in terms of Irigaray's insistence on the return to the pre-Oedipal stage. The final resolution of the novel, however, has its roots in the confusion of the father through this act. Robinson is a man who appreciates and adores the physicality of love in his wife but abhors it in the case of his daughter. He is aware of his dilemma when he says: "I did not understand her spirit. I yearned for guidance. It seemed to be necessary to tame her"(18). His words imply that, surrounded by the Mexican Black/Indian tribe and the ideals they live their lives by, he senses the error of his ways but cannot think of an alternative. The possibility of not interfering at all does not occur to him as the figure of authority. Faced with a situation he cannot fully comprehend, he resorts to physical power as the only course of 
action available for a man representing patriarchal order. His received understanding of power dictates the suppression of female sexuality and love by the male; thus he turns to the age old tried and tested way of giving Magdalena a furious and violent beating. Magdalena recalls the incident and the subsequent scars it has left on her soul as she says: "He trashed me in silence. I withstood it in silence. I sent my spirit flying out the window" (26). Unfortunately for everyone concerned, Robinson is not able to relate to and be guided by the traditions of the Mundo people or his own black heritage.

It is also at this point that the girl begins to feel enmity towards her sister and mother who says that she will leave her husband because of what he has done to Magdalena, but she never does. Even worse is the aftermath that Magdalena recalls: "Within a month, or less, my father loved my mother back to himself" (27). This will be perceived by Magdalena as an act of ultimate betrayal by her mother. Langley, who only had accepted to bear a child after making Robinson promise that they would never lay a hand on their child, and after the beating had wept "as if her heart would break" and screamed "We were beaten in slavery!" (31) is gradually won over by her husband.

Years later when Langley is dying of cancer, Magdalena reminisces about the bond that was lost between them. She says: "I was trying to remember how it felt to love her. For I ceased loving her when she abandoned me" (120). Susannah, too, carries this treachery like a wound in her body throughout her life and becomes a woman broken in body and spirit. Believing her own sexuality to be ultimately harmful to her being, she deliberately makes herself uglier by being obese, getting fatter by the day, as well as piercing herself in various parts of her body. The pierced cross through her labia could be read both as a protest against her father's pretence of priesthood and simultaneously as a revolt against the patriarchal religion with which he justifies his actions towards her. As Irigaray points out in An Ethics of Sexual Difference, patriarchal religion takes the supremacy of the male and the suppression of the female as the foundation stone. Another French feminist, Julia Kristeva, emphasizes the same issue when she writes in her article, "About Chinese Women," that "monotheistic unity is sustained through a radical separation 


\section{Ethnic Studies Review Volume 26: 1}

of the sexes: indeed, it is this very separation which is its prerequisite" (141). Hence, the female is marginalized within established religion unless she is defined in relation to the male. Her access to divinity is restricted strictly both in physical and spiritual terms. The only position she can occupy safely is that of being a vessel for the male. Within her allocated space the role of the female body is to be the bearer of Son/God. Susannah's cross pierced through her labia could be understood as a metaphor for this circumscribed relationship between the female body and patriarchal religion.

The traumatic course of events in the novel also severely damages not only Magdalena, the primary recipient of his violence, but also the relationship between Robinson and Susannah, his younger daughter. It could be argued that Susannah, along with her sister, also goes through the prescribed Oedipal break from her mother as well as from her sister. Moreover they are further alienated from each other because Magdalena believes that their father loved her more. This point on the rivalry between women for male approval and love constitutes an important step in the formation of the prescribed notions of female identity. In "Love of Same, Love of Other" in An Ethics of Sexual Difference Irigaray tries to construe this impossibility in terms of the competition between women for the maternal function which is the only female trait that is universally valued. She argues that since the mother has a unique place and being a mother means to occupy that place, the relationship with the mother becomes an impossibility; hence the issue evolves into an either/or, her/me requirement. As Irigaray posits, even this specifically female rivalry is played out in terms of male norms:

If we are to be desired and loved by men, we must abandon our mothers, substitute for them, eliminate them in order to be same. All of which destroys the possibility of a love between mother and daughter. The two become at once accomplices and rivals in order to move into the single possible position in the desire of man.

This competition equally paralyzes love among sister-women. Because they strive to achieve the post of 
the unique one: the mother of mothers, one might say (102).

However there can be no winners in such a rivalry. Admitting that "Father thinks Susannah beautiful only when she was moving very slowly, or when she was still" (92), Magdalena implies that father's love is not unconditional for Susannah either. It is likely that this is the underlying reason for the girl's fascination with Princess Diana. The appeal of the late Princess for the girl is indeed interesting because Princess Diana was haunted and criticized throughout her adult life by her nation. Unlike her namesake, the Roman goddess Diana, she became the hunted instead of the hunter. It is only after Princess Diana died and became perfectly still that she became almost a saint. Such a reaction to the death of a woman reminds the reader of the idea that the female is perfect when she is speechless and even dead. Robinson, too, seems to prefer Susannah because she can keep her spirit under control. The necessity to mould the female self according to the imperative imposed by the patriarchal thinking is an issue that is dealt closely by Irigaray as she writes in This Sex Which Is Not One: "The feminine occurs only within models and laws devised by male subjects" (86). The female is not capable of thinking herself in feminine terms, as the only path to her imagination is via masculine terms, which leads her to impossibility.

The only thing that sheds any light on the possibility of healing and the establishment of identity for these women, as well as their ability to enter into rewarding relationships with men, is the recovery of the bond between themselves and their mother along with their relationship with other women. The novel has many different women characters who differ in race, nationality, age, and experience. Although they do not share a common language, at times there is still communication between women without the use of words. When Susannah asks her Greek husband to be introduced to the Greek dwarf woman, Irene, who will play an important role in her understanding of herself and the world she lives in later on in the novel, she is refused with the excuse that she does not speak English. For Susannah this is not a valid point, as she states: "Oh, but she has eyes" (43). Her words imply that communication is not limited to language and 


\section{Ethnic Studies Review Volume 26: 1}

can be achieved through alternative means, through the body in the case of Susannah and Irene. The identification with different women allows the female characters to share their experiences and a kind of kinship is formed among them, as their lives have been so different but still so similar to their own. For instance Susannah shares a special moment with her white Greek mother-in-law when she questions and reminds the old woman about violence towards women in her youth. Her husband Petros recalls the moment as follows:

As she [Susannah] forged ahead, I saw a shift occur in my mother's look. Very odd. For I had known it all my life to be a face with a certain limited range of emotional expression. I did not recognize the looks she was beginning to give to my inquisitive wife. I saw my mother begin to awaken, against her will. As if from ancient sleep. To shake herself as an animal after hibernation might do. I saw her rouse her memory (46).

Unfortunately Petros dismisses the communication between the two women as unimportant. He quickly forgets the spiritual awakening in the eyes of his mother. He even draws Susannah away because he believes that his mother is uncomfortable. Petros, as a product of traditional patriarchal thinking, is unable to comprehend the importance of the bond that is established between his mother and Susannah. Two women separated from each other due to age, background, and culture, establish a connection as women through their bodies. Petros's lack of understanding marks a turning point in his relationship with Susannah as husband and wife. From then on Susannah begins to draw away from him.

The most striking and impressive of these female characters is Irene who is condemned to be the caretaker, or rather the servant, of a small church on a Greek island. Irene, putting forward alternative myths that predate the traditional patriarchal ones which allow woman to have a position of subjectivity, almost shakes Susannah back to herself. While arranging lilies for the service at the church, Irene says: "The lily is the flower of Lilith, the first mother. The rough one who was bored by Adam and went off to have adventures elsewhere. The one before Eve" (178). The reference to a time before the beginning of history and 
before the patriarchal binary oppositions have been established would serve as a metaphor for the pre-Oedipal stage in human development as well. In this stage the mother and the child are still in a continuum, and the bond between them has not been forcefully severed yet. Sexuality, both female and male, has not been forced into well-defined and hierarchical dichotomies. Irene reminds Susannah, as well as the reader, of the necessity to remember this long forgotten past when she says: "I think the human spirit needs to believe that someone has escaped the general pressing down of life that passes for the male notion of civilization" (141). Perhaps Irene, Langley, Magdalena, and Susannah, when they can achieve love for their own selves and for each other and be together as a community, can serve as that guiding spirit who struggles to remember and to remind.

Carried throughout the novel as a strong theme is another aspect in the process of healing: the act of making love. It is presented as an act that has the potential to eliminate the impossibility of self-love on behalf of the woman. The female characters in the novel are all trying to find a position to accommodate love of their own female identities. The theme of impossible female self-love could be read in terms of Irigarayan theory in which touching is a predominantly female activity. As the theoretician discusses in This Sex Which Is Not One, predominance of the visual lies in the realm of patriarchal thinking as the boy sees that he has a penis. The girl, on the other hand, does not possess visible sexual organs; hence she is branded as the castrated one. Irigaray attempts to explain this complex issue through the concept of visibility: since the male sexual organs are external, selflove remains attainable for man as he has a validated relation to exteriority, whereas this is not valid for the female. The female does not have the same relation to exteriority as the male, whose sexual organs are continuously on display. The woman's experience, on the other hand, is limited to the production she achieves through her body. In An Ethics she writes: "Woman is loved/ loves herself through the children she gives birth to. That she brings out" (63). This statement is particularly valid for the relationship between a mother and her son: the most perfect configuration love can take in terms of traditional psychoanalysis. Such a model by definition cannot result in self-love in the 


\section{Ethnic Studies Review Volume 26: 1}

woman's case in the true sense but only in the love of woman for her production; hence seeing could be considered further away from femininity compared to the sense of touch. Irigaray in This Sex argues this point as such:

Within this logic, the predominance of the visual, and of the discrimination and individualization of form, is particularly foreign to female eroticism. Woman takes pleasure more from touching than from looking, and her entry into a dominant scopic economy signifies, again, her consignment to passivity: she is to be the beautiful object of contemplation. (25-26)

Walker, along with Irigaray, prioritizes touch rather than sight. Throughout By The Light of My Father's Smile the act of touching is emphasized over and over again. It is a novel that is loaded with explicit descriptions of physical acts of love, and the scene between Susannah and her lover, Pauline, is a powerful one that concentrates on the multiplicity of female sexual organs (9-13). The prioritizing of touch dominating the scene shifts the attention away from the "nothing to see" attitude towards female sexuality. Instead of nothingness or insufficiency the reader is led towards an understanding of multiplicity, discovery, and acceptance.

Trying to establish a maternal genealogy has a part to play in this wide ranging and difficult task of redefinition of love. In An Ethics of Sexual Difference Irigaray posits that in order to displace the father (in the traditional patriarchal understanding of the term) from his central place, a quest for maternal genealogy is necessary even though it might be almost impossible, as it is a history which has been rendered invisible by the patriarchal system; therefore the task of the author is not only to clear up the rubble under which women have been buried and forgotten but to try to create a maternal genealogy through which they can relate to each other as women. A genealogy of mothers would again circumscribe woman within motherhood and would constitute the same hierarchy that women are trying to break through but with radically different reference points. Irigaray once again draws attention to this in This Sex when she writes about the urgent need of trying to imagine an identity for woman and rejecting such restricting representations: 


\section{Gorey-Re-Reading Love}

So many representations, so many appearances separate us from each other. They have wrapped us for so long in their desires, we have adorned ourselves so often to please them, that we have come to forget the feel of our own skin. Removed from our skin, we remain distant. You and I, apart (218).

This might be the reason why only through death, after they pass into another realm where the traditional definitions of sexuality are not valid any more, can Magdalena and Susannah make some sort of peace with their mother, for after death they meet according to more maternal tribal traditions of the Mundo people which allow such a reconciliation to take place, not the patriarchal Christian expectations of the father, Robinson. It is in the realm after death that Langley talks to Magdalena about her father's heart: "It was a frightened heart, she said. His people were enslaved people who in fact became slaves. You do not become free again by wishing it" (158). As can be seen, the morality which has been perpetuated by Robinson does not actually belong to him. He has internalized the prescriptions that have been imposed on him. Likewise the resolution between the father and the daughter can take place only when Robinson subscribes to the beliefs of the tribe that has connections with his own black heritage as well as his feminine side.

Women's lack of access to and failure to communicate with each other in genuine terms is somehow bridged in this other realm as was exemplified above through the communication between Langley and Magdalena. It is the only sincere dialogue between the mother and the daughter. Even though they do not achieve closure, as Magdalena still blames her mother for her abandonment, they take a few timid steps towards reconciliation.

As opposed to the possibility of reconciliation in the realm after death, the need for such a connection in real life is quite problematic within the existing status quo. This is an issue both Walker and Irigaray dwell upon in their work. In her essay, "Love of Self," in An Ethics Irigaray's comment, "The possibility that the female could be many; that women would form a social group" (67), points up one of the lifelines which the two authors agree upon, a goal not attainable: they are abandoned to a state of nei- 


\section{Ethnic Studies Review Volume 26: 1}

ther knowing each other nor loving each other, or themselves; love remains impossible for them (67).

This idea of love of self for a woman is quite subversive, as traditionally woman is the bearer of selfless love for everyone but herself. She has been the epitome of love as a mother, wife, and daughter. These are all positions that are defined in relation to the male; therefore historically she has been the building block of man's love for self. Such a role is a very restricting one denying woman access to love for her own self; hence seeking other women out and associating with them is an important step towards discovery of the female love for her self as the idea is explored throughout the novel.

Walker in the same vein works toward locating a female tradition and establishing a bond between women in order to make possible a redefinition of love. In her essay, "Saving the Life That Is Your Own: The Importance of Models in the Artist's Life," collected in Mary Eagleton's Feminist Literary Theory, the author traces the footsteps of her maternal predecessors in order to give an order to her own self both as a woman and as a writer. She recalls how writing a story about her own mother was made possible through her discovery of other authors who paved the way for her. She says: "It is, in the end, the saving of lives that we writers are about. Whether we are 'minority' writers or 'majority.' It is simply in our power to do this. ... We care because we know this: The life we save is our own" (33). By making a vital connection between herself and her female ancestors Walker puts forward the idea of self love attained through connection and continuity. It is only through locating oneself in relation to others that are the same that the state of the loving subject can be attained. The short Mundo prayer quoted in the beginning of the novel also points out such an understanding. It reads:

Mama

help us

to help

you.

The prayer is significant in that it captures the connection between women as a community with a strong healing bond between them. The foundation stone in such a process of healing is identified as the mother who has the power to initiate 
change. The prayer also serves as a starting point for Walker's novel in the quest towards an alternative understanding of love as opposed to its patriarchal definition in terms of power and domination.

The words of the poet, Adrienne Rich, are also quite useful in such a context. In her powerful essay, "When We Dead Awaken," collected in On Lies, Secrets and Silence, Rich writes:

The choice still seemed to be between "love"-woman-

ly, maternal love, altruistic love-a love defined and ruled by the weight of an entire culture; and egotism-a force directed by men into creation, achievement, ambition, often at the expense of others, but justifiably so. For weren't they men, and wasn't that their destiny as womanly, selfless love was ours? We know now that the alternatives are false ones-that the word "love" is itself in need of re-vision (46-47).

Being the guardian of love for everyone but herself is indeed a very costly duty for the woman. In order for the act of re-vision to be achieved, woman has to be free of the complete reliance on man for the return of self-love. Self-love by definition has to come from within the woman's body and through her connection with the mother. Self-love can be attained in relatively simpler terms for man. He has to renounce his mother so that he can love himself. This act of renunciation does not forbid him to love himself; however a woman not only has to renounce her love of her mother but also her own identification with her. She is obliged to follow this path so that she can love a man, the father figure. This is the formula that Magdalena goes through in the novel. The outcome, however, is not so straightforward, as the abandonment of the mother and the encounter with the male violence result in the loss of her self. This foundation that affects every relationship in her life turns out to be insufficient and actually harmful. As Magdalena says referring to her mother: "I was trying to remember how it felt to be her. For I ceased loving her when she abandoned me" (120).

Exploring these ideas, as well as emphasizing the need for a woman-to-woman relationship with the mother and other women implies the commitment of Alice Walker to the female principle. Irigaray terms these relationships "vertical" (daughter- 


\section{Ethnic Studies Review Volume 26: 1}

to-mother, mother-to-daughter) and "horizontal" (among women, or among "sisters") in An Ethics (108). The term, "female principle," in my understanding, involves love of the self as well as love of the other without domination or destruction. These are issues to which both Irigaray and Walker are deeply committed in their work. Such explorations would enable us to claim love in its revised understanding for ourselves and the people around us, as the abandonment of the mother is harmful not only for the woman but also for the man, as their relationship is deeply hurt. The following words uttered in regret by Robinson underline the idea that it is not only woman but woman and man together who are damaged irreparably. He says:

There was something in me, I found, that followed ideas, beliefs, edicts, that had been put into practice, into motion, before I was born. And this 'something' was like an internalized voice that drowned out my own. Beside which, indeed, my own voice began to seem feeble. Submissive. And when I allowed myself to think about that submission I thought of myself as having been spiritually neutered. And thought, as well, of the way Langley, Magdalena, and even the all-accepting Susannah sometimes looked at me. In dismay and disappointment. Daddy, the girls seemed to ask, where is your own spark? Langley seemed resigned to the fact that it was missing. (30)

Walker widens this view globally and attacks all of Western civilization by emphasizing the fact through Irene when she says: "Europe lost her strong mother. By doing that it killed off its mother and was made to shrink its spirit to half its size" (186). The quotation is a good example of Walker's critique of Western patriarchal thought based on the exclusion of the feminine. Manuelito explicitly emphasizes the point when he says: "The Story you were telling us, Señor Robinson, was strange" (147). Robinson's story, learned from patriarchal establishments such as religion, fails to make sense for the Mundo people. They feel confused with the prescribed exclusion of the sexes leading to hierarchy. For a tribe which considers both male and female sexuality as sources of joy and healing, Western European tradition does not present itself as a promising alternative. 
The resolution of the novel that takes place for all the characters involved is symbolized by the Mundo initiation song taught to Robison by Manuelito who are both dead. This song of crossing is what enables the characters to resolve the conflicts between their own selves and each other as well as the clash of the cultures that is embodied in the person of Robinson. Only by making a long lost connection with the mother, re-establishing the positive and fruitful relationship between man/woman and mother/father through the tribal guidance of Manuelito can Robinson, Langley, Magdalena, and Susannah achieve peace. The following section from the song of crossing explains how such a peace becomes possible for them:

Anyone can see that woman is the mother

of the oldest man on earth

is it not then a prayer

to bow before her?

Anyone can see that man is the father

of the oldest woman on earth

is it not then a prayer

to bow before him? (161)

By unearthing the long abandoned maternal bond, the author creates a space through which she can maneuver. In order to be able to break through the values and behaviors that seem to be repeated generation after generation, Walker seems to propose to re-establish our union with the mother and with other women in order to exist in a happy relationship with men and our community on earth. This simultaneously vertical and horizontal connection will enable us to name and claim self-love for ourselves as daughters and mothers, instead of succumbing to the myth of the selfless woman whose identity and sexuality is prescribed by foreign terms. By the Light of My Father's Smile is the embodiment of Walker's efforts to involve mother and daughter together in this exploration. Such an involvement, which has the potential to redefine the understanding of the term, "love," has wide and positive implications for the future. 


\section{Ethnic Studies Review Volume 26: 1}

\section{Works Cited}

Irigaray, Luce. An Ethics of Sexual Difference. Burke, Carolyn and Gillian C. Gill

(trans.). London: The Athlone Press, 1993

-------. This Sex Which Is Not One. Catherine Porter (trans.). New York: Cornell UP, 1996.

Kristeva, Julia, 'About Chinese Women', Moi, Toril (ed.), The Kristeva Reader, London: Blackwell, 1993, p. 141.

Rich, Adrienne. "When We Dead Awaken". On Lies, Secrets and Silence: Selected Prose: 1966-1978. London: Virago Press, 1995: 467.

Walker, Alice. In Search of Our Mother's Gardens: Womanist Prose. San Diego, CA: Harcourt Brace Jovanovich, 1983.

------ 'Saving the Life That is Your Own: The Importance of Models in the Artist's Life', Eagleton Mary (ed.), Feminist Literary Theory: A Reader, London: Blackwell, 1996: 30-3.

-----. By the Light of My Father's Smile. New York: Random House, 1998. 